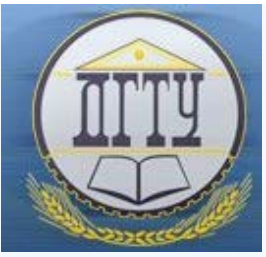

\title{
Probabilistic design strategy for improved Austin-Moore stem used in artificial cementless hip prosthesis considering material property uncertainty
}

\author{
G. Kharmanda ${ }^{1}$, I. R. Antypas ${ }^{2}$ \\ ${ }^{1}$ INSA Rouen Normandie (Saint-Etienne-du-Rouvary, France) \\ ${ }^{2}$ Don State Technical University (Rostov-on-Don, Russian Federation)
}

Introduction. The use of probabilistic analysis is important when the input data are random, that leads to stochastic results. This paper describes the integration of a probabilistic design strategy of the solid and hollow stems implanted in a proximal femur in order to compare their advantages. The used hollow stem is called "Improved Austin-Moore" (IAM) model.

Materials and Methods. Probabilistic methods allow variations in factors which control the biomechanical effects of the implanted femur to be taken into account while determining its performance. Different material properties were generated randomly using Monte Carlo simulation (MCS). Monte Carlo sampling techniques were applied, and different von Mises stresses of the layers (bone and metal) were chosen as a performance indicator.

Results. A simple 2D implant-bone study of solid and IAM stem design was carried out with a high level of confidence, $99.87 \%$, which corresponds to a target reliability index with regard to statistical uncertainties. The probabilistic design results show that the input and output parameters for the IAM stem are highly correlated relative to those for the solid stem.

Discussion and Conclusions. The sensitivity analysis shows that the input parameters for the IAM stem play a much larger part in the output parameters relative to the solid stem. The IAM stem is much more advantageous than the solid stem which causes an increase in the performance of the hip prosthesis.

Keywords: hip prosthesis, probabilistic analysis, finite element analysis, Monte Carlo simulation, IAM model.

For citation: G. Kharmanda, I. R. Antypas. Probabilistic design strategy for improved Austin-Moore stem used in artificial cementless hip prosthesis considering material property uncertainty. Advanced Engineering Research, 2020, vol. 20, no. 3, p. 216-224. https://doi.org/10.23947/2687-1653-2020-20-3-216-224

(C) Kharmanda G., Antypas I. R. 2020

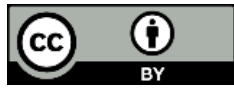

\section{Вероятностная стратегия проектирования усовершенствованного стержня Остина- Мура, используемого в искусственном бесцементном эндопротезе тазобедренного сустава}

\section{М. Г. Харманда ${ }^{1}$, И. Р. Антибас ${ }^{2}$}

${ }^{1}$ INSA Rouen Normandie (Saint-Etienne-du-Rouvary, France (Сент-Этьен-дю-Рувре, Франция)

${ }^{2}$ ФГБОУ ВО «Донской государственный технический университет» (г. Ростов-на-Дону, Российская Федерация)

Введение. использование вероятностного анализа важно тогда, когда входные данные случайны, что приводит к стохастическим результатам. Эта статья описывает интеграцию вероятностной стратегии проектирования сплошных и полых стержней, имплантируемых в проксимальный отдел бедра, для проведения сравнения их преимуществ. Используемый полый стержень получил название «Улучшенная модель Остина-Мура» (IAM).

Maтериаль и методы. Вероятностные методы позволяют учитывать различия в факторах, контролирующие биомеханические эффекты имплантированного бедра при определении его эффективности. Различные свойства применяемого материала генерировались случайным образом с помощью метода Монте-Карло (MCS), который также был использован для выборки проб, а в качестве показателя эффективности были выбраны различные напряжения по-Мизесу слоёв (кости и металла). 
проводился с высоким уровнем достоверности - 99,87\%, что соответствует целевому индексу надежности с учетом статистической неопределенности. Результаты вероятностного проектирования показывают, что входные и выходные параметры для стержня IАМ сильно коррелированы относительно параметров сплошного стержня.

Обсуждение $u$ выводы. Анализ чувствительности показывает, что входные параметры для IАМ - стержня играют гораздо более значительную роль в выходных параметрах по сравнению со сплошным стержнем. Стержень IAM намного более выгоден, чем стержень сплошного сечения, что приводит к повышению производительности протеза тазобедренного сустава.

Ключевые слова: протез бедра, вероятностный анализ, анализ методом конечных элементов, моделирование по методу Монте-Карло, модель ІАМ.

Для цитирования: Харманда, М. Г. Вероятностная стратегия проектирования усовершенствованного стержня Остина-Мура, используемого в искусственном бесцементном эндопротезе тазобедренного сустава / М. Г. Харманда, И. Р. Антибас // Advanced Engineering Research. — 2020. — Т. 20, №3. — С. $216-224$. https://doi.org/10.23947/2687-1653-2020-20-3-216-224

\section{Introduction}

In probabilistic studies on Total Hip Replacement (THR) models, several important random parameters may affect the hip performance, such as the geometrical description of the bone, the implant and the cement, the material properties of different layers, the magnitude and direction of the applied loads, and the position of the bone-implant [1, 2]. In order to improve the stem design, several points have been considered. At the first stage, the rectangular section stem is considered more reliable than the circular section stem [3]. The rectangular section stem then provides a secure diaphyseal press-fit in the frontal plane of the femoral canal. This way it allows excellent rotational stability and improves the primary mechanical fixation [1]. In addition, wear as mentioned in Kharmanda and Albashi [4] can be reduced. At the second stage, the shouldered stem is considered more reliable than the non-shouldered one. It has been shown in the numerical results of Kharmanda, et al. [5], that, when considering the shouldered stem, there is an excellent decrease of the maximum values on von Mises stress in different bone layers compared to the non-shouldered one. At the third stage, the hollow stems are considered. In Kharmanda [6], a multi-objective structural optimization strategy has been integrated into Austin-Moore prosthesis in order to improve its performance. The resulting model was called Improved Austin-Moore (IAM). The topology optimization was considered as a conceptual design stage to sketch the IAM stem according to the daily loading cases. The shape optimization presented the detailed design stage considering several objectives. A new multiplicative formulation has been proposed as a performance scale to define the best compromise between several requirements. In this paper, a probabilistic design strategy is applied on two kinds of stems (solid and IAM stems) to determine the mechanical effects, the response sensitivities with respect to input parameters, and the correlation of the used material properties with different output parameters. A numerical application on a $2 \mathrm{D}$ problem is carried out to show the advantages of the IAM stem relative to the solid one.

\section{Material and methods}

2.1 Model description and material properties

Fig. $1 a$ and $b$ show 2D sections for the studied solid and IAM stems implanted in bone layers (cortical bone and cancellous bone). The bone materials are generally anisotropic [7]. In the current study, the material properties of bone have been for simplicity considered as linearly elastic and isotropic. In Fig. 1, the cortical bone material is considered to be homogeneous and isotropic with Young's modulus $E=17 \mathrm{GPa}$ and Poisson's ratio $v=0.33$. The corresponding number of elements for the cortical region is 605 elements for the solid stem model, while it is 545 elements for the IAM stem model. The cancellous bone material is also considered to be homogeneous and isotropic with Young's modulus $E=386 \mathrm{MPa}$ and Poisson's ratio $v=0.33$ [8]. The corresponding number of elements for the cancellous region is 417 elements for the solid stem model, while it is 418 elements for the IAM stem model. The modulus of titanium alloy of stem is considered to be: $E=110 \mathrm{GPa}$ with Poisson's ratio: $v=0.3$ [9]. The corresponding number of elements for the metal region is 529 elements for the solid stem model, while it is 861 elements for the IAM stem model. The used element is PLANE82 (8-node, nonlinear). The number of the total nodes is 5048 nodes for the solid stem model, while it is 6094 nodes for the IAM stem model. 


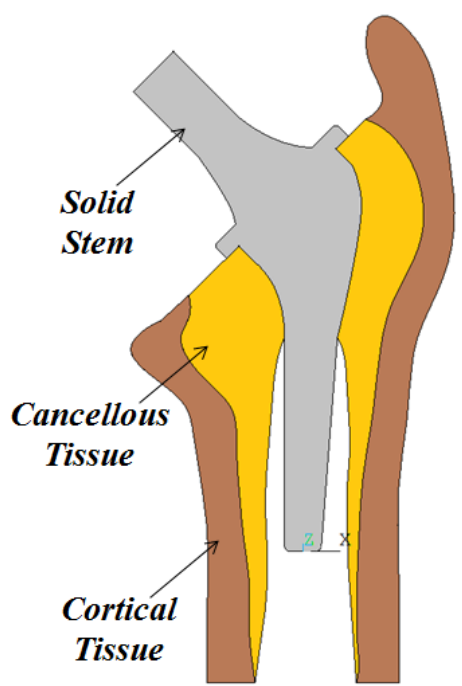

a)

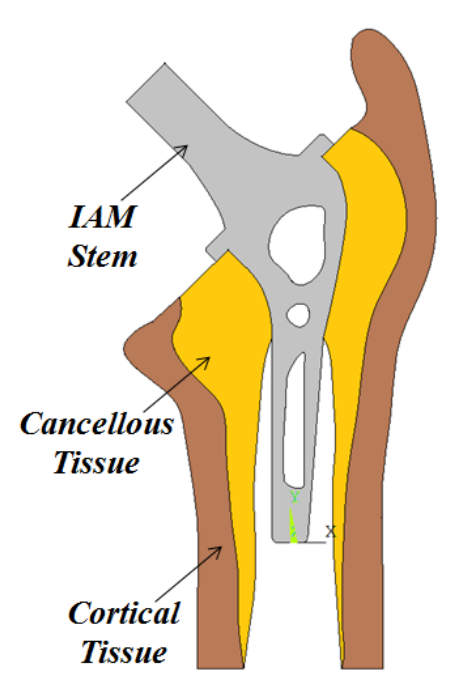

b)

Fig 1. Geometry models for: $a$ ) solid stem and; $b$ ) IAM one

\subsection{Boundary conditions}

The loading cases are considered as daily loading conditions [10]: one-legged stance (L1), extreme ranges of motion of abduction (L2), and adduction (L3) as shown in Fig. 2.

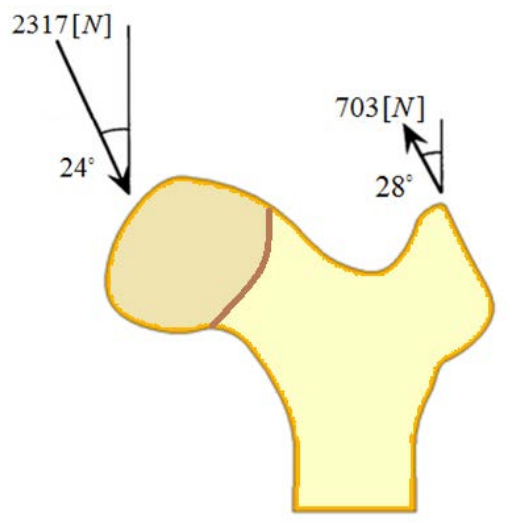

a)

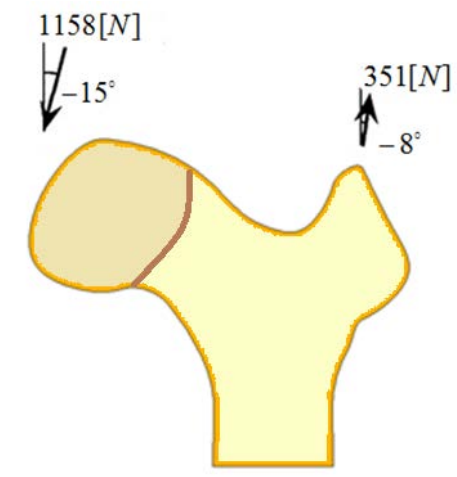

b)

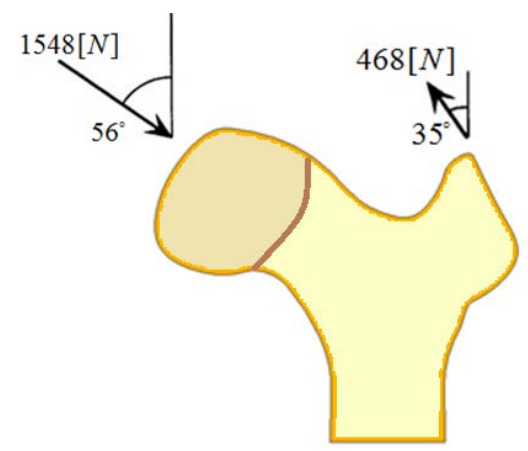

c)

Fig. 2. Loading cases: $a$ ) One-legged stance case (L1); $b$ ) Abduction case (L2); and c) Adduction case (L3)

Table 1 presents different components of the three loading cases (L1, L2 and L3) which are illustrated in Fig. 1.

Table 1

Force components

\begin{tabular}{|c|c|c|c|c|}
\hline \multirow{2}{*}{$\begin{array}{c}\text { Loading } \\
\text { Case }\end{array}$} & \multicolumn{2}{|c|}{ Body Forces } & \multicolumn{2}{c|}{ Muscle Forces } \\
\cline { 2 - 5 } & $F_{x}^{B}[\mathrm{~N}]$ & $F_{y}^{B}[\mathrm{~N}]$ & $F_{x}^{M}[\mathrm{~N}]$ & $F_{y}^{M}[\mathrm{~N}]$ \\
\hline L1 & 942.41 & -2116.68 & -330.04 & 620.71 \\
\hline L2 & -299.71 & -1118.54 & 48.85 & 347.58 \\
\hline L3 & 1283.35 & -865.63 & -268.43 & 383.36 \\
\hline
\end{tabular}

According to the results of Kharmanda [6], the third loading case (L3) leads to the highest von Mises stress values in the bone tissues. Thus, in this work, a probabilistic design strategy is performed considering the third loading case L3.

2.3 Probabilistic design strategy

2.3.1 Failure probability

The design of structures and the prediction of their good performance lead to the confirmation of a certain number of rules depending on the knowledge of physical and mechanical experience of designers. Thus, there are 
several events leading to a failure mode. It is the objective to evaluate the probability of failure corresponding to the occurrence of critical failure scenarios. The probability of failure is then given by:

$$
P_{f}=\operatorname{Pr}[G(\mathrm{x}, \mathrm{y})]=\int_{G(\mathrm{x}, \mathrm{y}) \leq 0} f_{Y}(\mathrm{y}) d y_{1} \ldots d y_{n}
$$

where $G(\mathrm{x}, \mathrm{y})$ is a limit state surface (curve) that is defined by the condition of good structural performance [11]. The limit state surface (curve) $G(\mathrm{x}, \mathrm{y})=0$ is located between the failure part $G(\mathrm{x}, \mathrm{y})<0$ and the safety part $G(\mathrm{x}, \mathrm{y})>0$. $f_{Y}(\mathrm{y})$ is the density function of the random parameter $\mathrm{Y}$. Several techniques can be used to compute the probability of failure. Monte Carlo Simulation (MCS) is the most conservative probability technique [12]. Here, the parameters are sampled at random from their underlying distributions and the probability of failure which is estimated by solving the model repeatedly. For all time, the MCS gives the correct solution if a sufficient number of trials is computed, but it requires a high computing time. In order to decrease this expense, and avoid overlapping of samples and/or lack of samples in some regions of the domain, another technique called Latin Hypercube Sampling (LHS) can be applied [13]. The MCS based approach divides the sample space into separate intervals with equal probabilities, and one sample is randomly taken from each interval. When considering implicit models, finite element analysis has been combined with probabilistic design methods in order to allow uncertainty in the system parameters to be taken into account. Several types of uncertainties can be distinguished:

- Physical uncertainty: For example: material properties, dimensions, loading, etc.;

- Statistical uncertainty: Due to limited sample sizes, probabilistic model is considered uncertain;

- Model uncertainty: For example, mathematical models, numerical approaches due to simplifying assumptions, unknown boundary conditions, and unknown effects of other variables that are not included in the model.

\subsubsection{Reliability index}

The reliability is the inverse of failure probability. The relationship between the reliability $R$ is related with the failure probability, it can be written as follows:

$$
P_{f}=1-R
$$

To estimate the reliability index, several techniques have been developed during the last five decades, namely FORM (First Order Reliability Methods), SORM (Second Order Reliability Method) and simulation techniques [11, 14]. In FORM approximation, the probability failure is simply evaluated by

$$
P_{f} \approx \Phi(-\beta)
$$

where $\Phi(\bullet)$ is the standard Gaussian cumulated function calculated through the following integral:

$$
\Phi(Z)=\frac{1}{\sqrt{2 \pi}} \int_{-\infty}^{Z} e^{-\frac{z^{2}}{2}} d z
$$

For practical engineering applications, Eq. (3) gives sufficiently accurate estimation of the failure probability. In general, the nuclear and spatial studies necessitate very small values of failure probability, the failure probability should be: $P_{f} \in\left[10^{-6}-10^{-8}\right]$ that corresponds to a reliability index $\beta \in[4.75-5.6]$ when using equations 3 and 4 ; while in structural engineering studies, the failure probability should be: $P_{f} \in\left[10^{-3}-10^{-5}\right]$ that corresponds to a reliability index $\beta \in[3-4.25]$ (A detailed study on target safety indices can be found in Jeppsson [15]. In the next section, a simple 2D implant-bone study of solid and IAM stem designs is presented with account for statistical uncertainties.

\section{Results}

The Probabilistic Design System in ANSYS software analyzes a component or a system involving uncertain input parameters. The input parameters concerning geometry, material properties, boundary conditions, etc., are defined in ANSYS software. The variation of these input parameters is considered as random input variables and is characterized by their distribution type (normal, lognormal, etc.), as well as their distribution parameters (mean values, standard deviation, etc.). The important responses are defined as random output parameters. During a probabilistic study, the software executes multiple analysis loops to compute random output parameters as a function of a set of random input variables. The values for the input variables are generated randomly using Monte Carlo simulation.

The studied model has six parameters that are regarded as random input parameters. Thus, six sources of uncertainty were considered in the present investigation: $E_{C a n}, E_{C o r}, E_{M}, v_{C a n}, v_{C o r}$ and $v_{M}$. These sources are Young's modulus and Poisson's Ratio for the three studied layers (cortical, cancellous and metal layers). According to several references in the literature [16, 17], the maximum and the minimum values of Young's modulus are respectively 19.7 $\mathrm{GPa}$ and 10.4 GPa for the cortical tissue, 5.6 GPa and $192 \mathrm{MPa}$ for the cancellous tissue, and $120 \mathrm{GPa}$ and $100 \mathrm{GPa}$ for the titanium alloy. And the maximum and the minimum values of Poisson's ratio are respectively $0.33 \mathrm{GPa}$ and $0.3 \mathrm{GPa}$ 
for the cortical tissue and for the cancellous tissue, while they are: 0.36 and 0.3 for the titanium alloy. It is considered that the input parameters follow the uniform distribution law. To assess the accuracy of the results, it is performed with a high confidence interval of $99.87 \%$ (reliability level). The failure probability is noted to be $0.13 \%$ which corresponds to a reliability index equal to $\beta=3$ (Equations 3 and 4). Using Sampling Method, Monte Carlo based simulations were run, with 30000 simulations for the third loading case (L3) on the solid and IAM stems. A sensitivity analysis was performed to assess the influence of each parameter on the maximum von Mises stress values for the cortical and cancellous bone, and for the metal $\left(\sigma_{\max }^{1}, \sigma_{\max }^{2}\right.$ and $\sigma_{\max }^{M}$ ). The evaluation of the sensitivities was based on both Rankorder correlation coefficients between the input parameters and the output parameters.

Table 2

Statistics of the random input and output parameters for solid stem

\begin{tabular}{|c|c|c|c|c|c|c|}
\hline Parameter & Mean & $\begin{array}{c}\text { Standard } \\
\text { Deviation }\end{array}$ & Skewness & Kurtosis & Minimum & Maximum \\
\hline$E_{C a n}(\mathrm{MPa})$ & 2896 & 1561 & $-1.73 \times 10^{-7}$ & $6.65 \times 10^{4}$ & 192.1 & 5600. \\
\hline$E_{C o r}(\mathrm{MPa})$ & $1.51 \times 10^{4}$ & 2685 & $2.06 \times 10^{-7}$ & $6.65 \times 10^{4}$ & $1.04 \times 10^{4}$ & $1.97 \times 10^{4}$ \\
\hline$E_{M}(\mathrm{MPa})$ & $1.10 \times 10^{5}$ & 5774 & $2.36 \times 10^{-7}$ & $6.65 \times 10^{4}$ & $1.00 \times 10^{5}$ & $1.20 \times 10^{5}$ \\
\hline$v_{C a n}$ & 0.3150 & $8.66 \times 10^{-3}$ & $-5.96 \times 10^{-7}$ & $6.65 \times 10^{4}$ & 0.3000 & 0.3300 \\
\hline$v_{C o r}$ & 0.3150 & $8.66 \times 10^{-3}$ & $1.39 \times 10^{-6}$ & $6.65 \times 10^{4}$ & 0.3000 & 0.3300 \\
\hline$v_{M}$ & 0.3300 & $1.73 \times 10^{-2}$ & $5.56 \times 10^{-7}$ & $6.65 \times 10^{4}$ & 0.3000 & 0.3600 \\
\hline$\sigma_{\max }^{1}(\mathrm{MPa})$ & 16.93 & 1.783 & 1.992 & $2.49 \times 10^{5}$ & 14.81 & 25.06 \\
\hline$\sigma_{\max }^{2}(\mathrm{MPa})$ & 7.057 & 0.7837 & 2.311 & $3.34 \times 10^{5}$ & 6.333 & 11.24 \\
\hline$\sigma_{\max }^{M}(\mathrm{MPa})$ & 11.28 & $1.44 \times 10^{-2}$ & $-1.42 \times 10^{-2}$ & $6.65 \times 10^{4}$ & 11.26 & 11.31 \\
\hline
\end{tabular}

Tables 2 and 3 show the statistical results of the random input and output parameters for the solid stem and for the IAM stem, respectively.

Table 3

Statistics of the random input and output parameters for the IAM stem

\begin{tabular}{|c|c|c|c|c|c|c|}
\hline Parameter & Mean & $\begin{array}{c}\text { Standard } \\
\text { Deviation }\end{array}$ & Skewness & Kurtosis & Minimum & Maximum \\
\hline$E_{C a n}(\mathrm{MPa})$ & 2896 & 1561 & $-1.57 \times 10^{-7}$ & $6.65 \times 10^{4}$ & 192.0 & 5600. \\
\hline$E_{C o r}(\mathrm{MPa})$ & $1.51 \times 10^{4}$ & 2685 & $1.71 \times 10^{-7}$ & $6.65 \times 10^{4}$ & $1.04 \times 10^{4}$ & $1.97 \times 10^{4}$ \\
\hline$E_{M}(\mathrm{MPa})$ & $1.10 \times 10^{5}$ & 5774 & $3.08 \times 10^{-7}$ & $6.65 \times 10^{4}$ & $1.00 \times 10^{5}$ & $1.20 \times 10^{5}$ \\
\hline$v_{C a n}$ & 0.3150 & $8.66 \times 10^{-3}$ & $5.64 \times 10^{-7}$ & $6.65 \times 10^{4}$ & 0.3000 & 0.3300 \\
\hline$v_{C o r}$ & 0.3150 & $8.66 \times 10^{-3}$ & $-5.93 \times 10^{-7}$ & $6.65 \times 10^{4}$ & 0.3000 & 0.3300 \\
\hline$v_{M}$ & 0.3300 & $1.73 \times 10^{-2}$ & $3.34 \times 10^{-8}$ & $6.65 \times 10^{4}$ & 0.3000 & 0.3600 \\
\hline$\sigma_{\max }^{1}(\mathrm{MPa})$ & 16.92 & 1.822 & 1.963 & $2.43 \times 10^{5}$ & 14.76 & 25.18 \\
\hline$\sigma_{\max }^{2}(\mathrm{MPa})$ & 7.081 & 0.7954 & 2.295 & $3.28 \times 10^{5}$ & 6.345 & 11.33 \\
\hline$\sigma_{\max }^{M}(\mathrm{MPa})$ & 11.30 & $1.18 \times 10^{-2}$ & $-1.78 \times 10^{-2}$ & $6.65 \times 10^{4}$ & 11.28 & 11.32 \\
\hline
\end{tabular}

Fig. 3 shows the probability density function histograms of output parameters. Fig. $3 a$ and $b$ show the histograms of the maximum von Mises stress value $\left(\sigma_{\max }^{1}\right)$ for the solid stem, and the IAM stem, respectively. Fig. $3 c$ and $d$ show the histograms of the maximum von Mises stress value $\left(\sigma_{\max }^{2}\right)$ for the solid stem, and the IAM stem, respectively. Fig. $3 e$ and $f$ show the histograms of the maximum von Mises stress value $\left(\sigma_{\max }^{M}\right)$ for the solid stem, and 
the IAM stem, respectively. The probability density function calculates an appropriate number of classes based on the number of samples. The number of classes is equal to the number of bars which are presented in the histogram. The distance between the smallest and largest sample value is divided into classes of equal width. A histogram is modeled by counting the number of hits in the individual classes and dividing this number by the total number of samples. Thus, a histogram represents the relative frequencies of the random quantity that is drawn for.

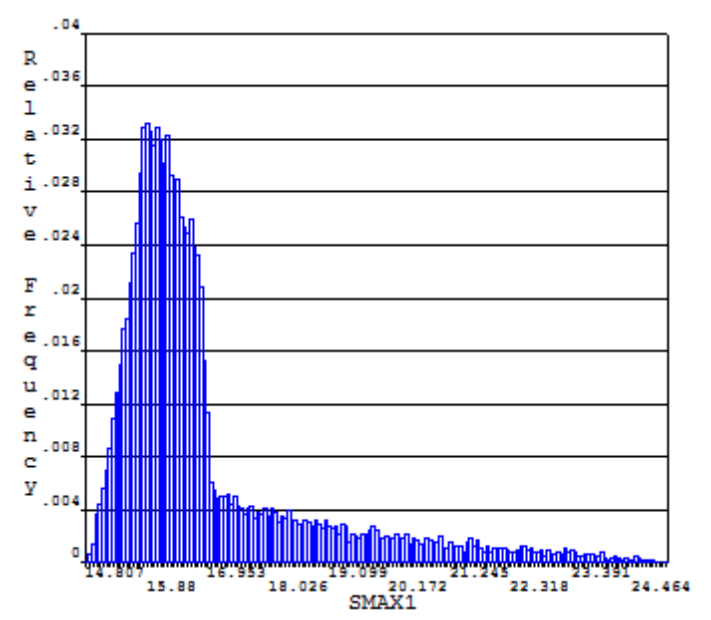

a)

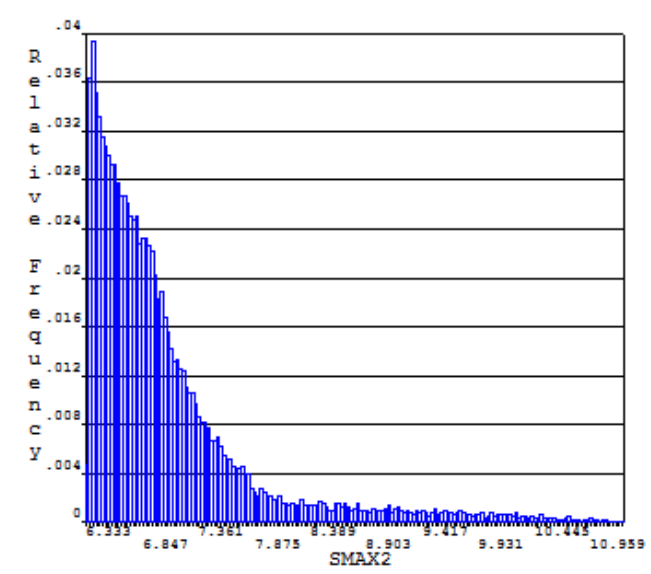

c)

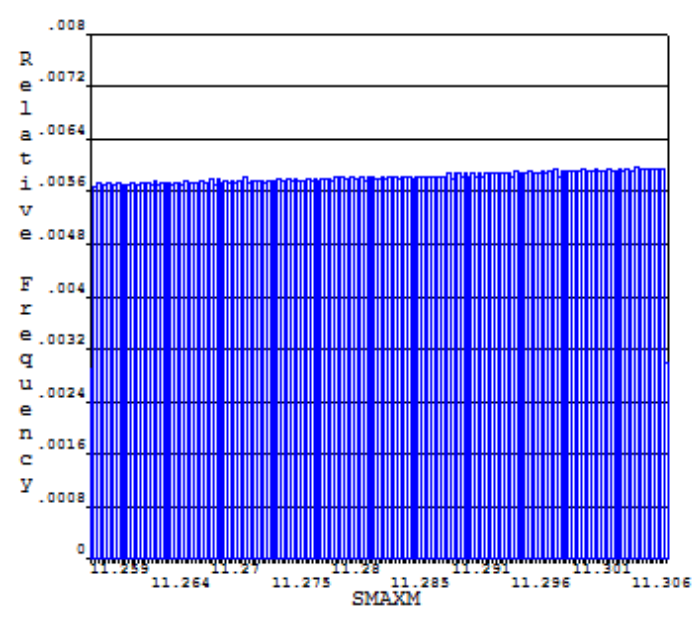

e)

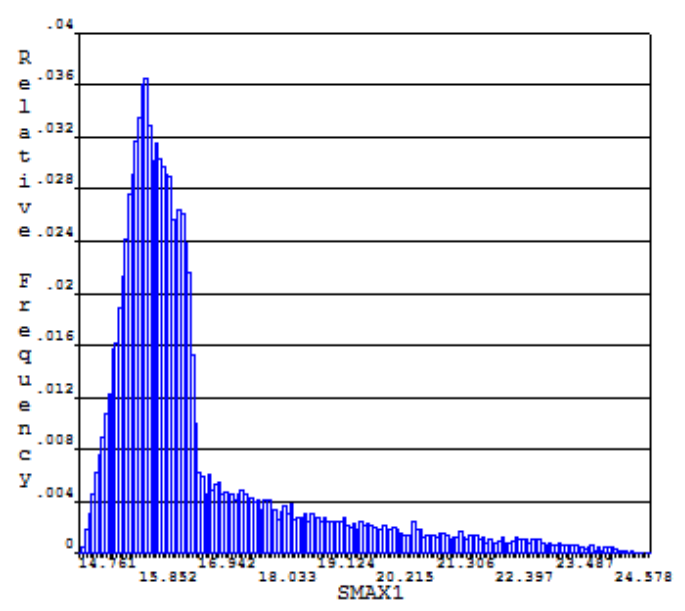

b)

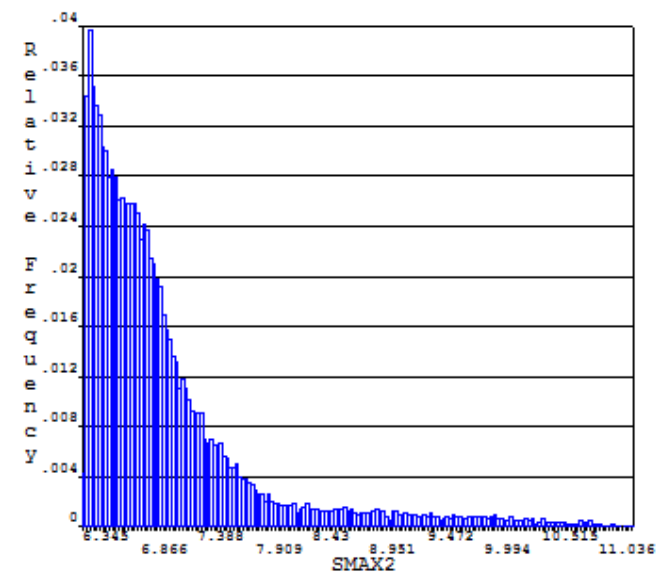

d)

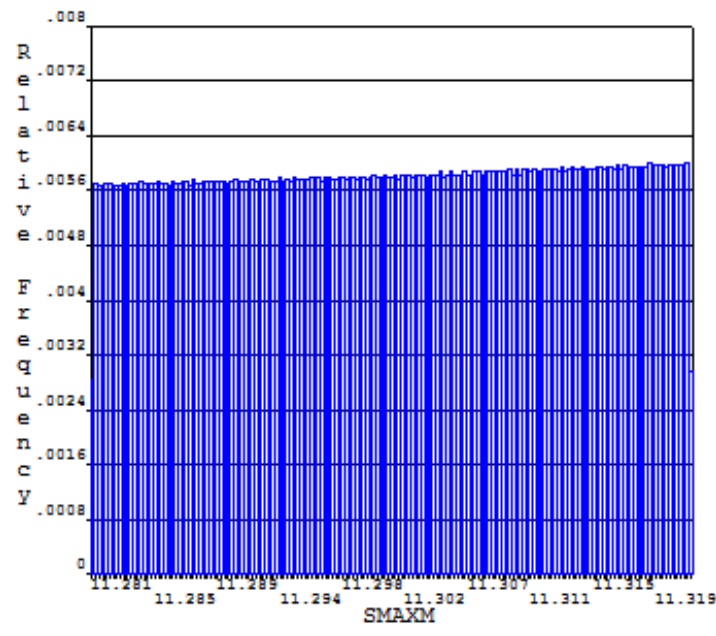

f)

Fig. 3. Histograms of the output parameters: $\sigma_{\max }^{1}$ for $a$ ) solid stem; $b$ ) IAM stem; $\sigma_{\max }^{2}$ for; $c$ ) solid stem; d) IAM stem; $\sigma_{\max }^{M} e$ ) solid stem, and $f$ ) IAM stem.

Fig. 4 shows the sensitivity evaluation of the output parameter with respect to the input random variables:

Fig. $4 a$ and $b$ show the sensitivities of the maximum von Mises stress value $\left(\sigma_{\max }^{1}\right)$ for the solid stem, and the IAM 
stem, respectively. Fig. $4 c$ and $d$ show the sensitivities of the maximum von Mises stress value $\left(\sigma_{\max }^{2}\right)$ for the solid stem, and the IAM stem, respectively. Fig. $4 e$ and $f$ show the sensitivities of the maximum von Mises stress value $\left(\sigma_{\max }^{M}\right)$ for the solid stem, and the IAM stem, respectively. The sensitivities of a certain random output parameter are modeled. The random input parameters are separated into two types: significant parameters and insignificant parameters. The sensitivity plots include only the significant random input parameters.

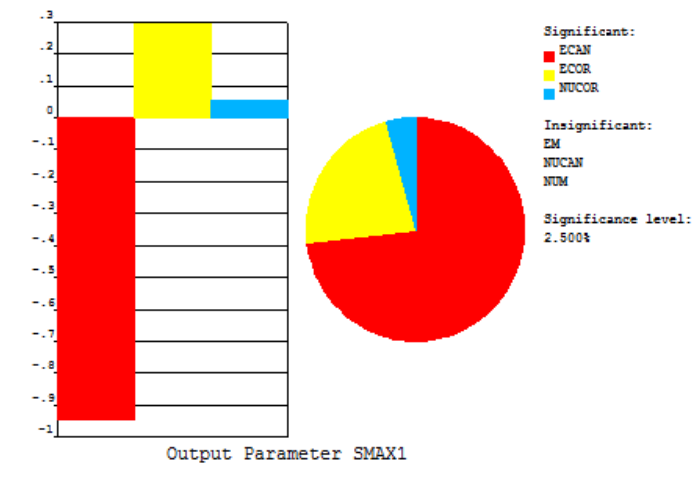

a)

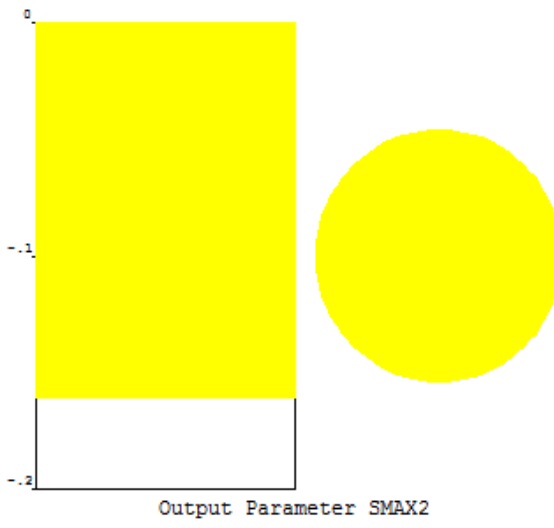

c)

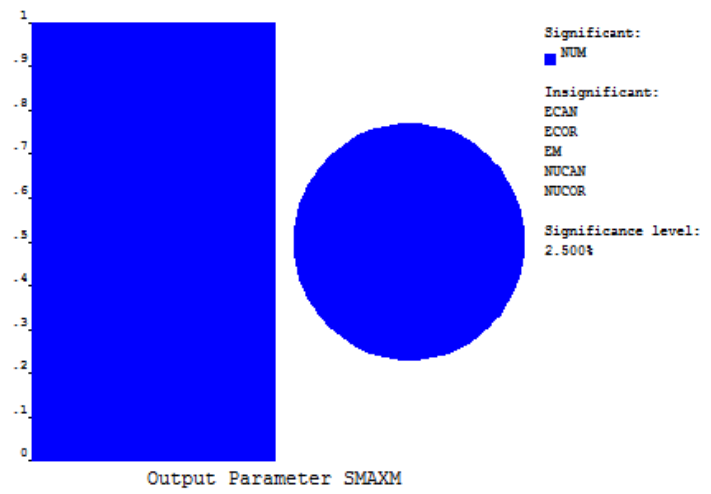

e)

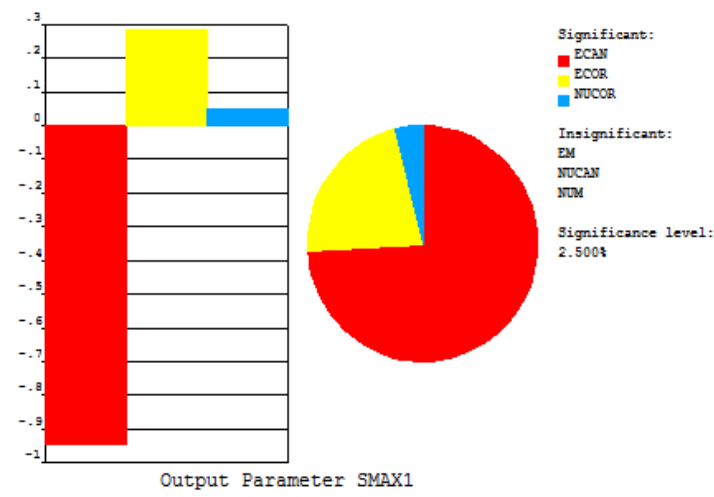

b)

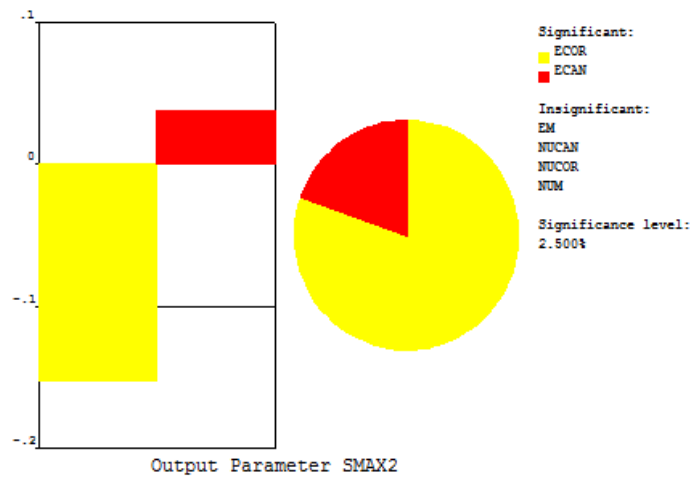

d)

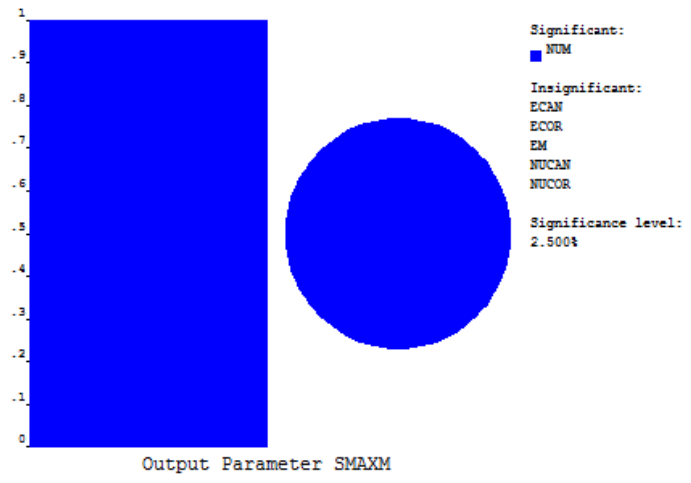

f)

Fig. 4. Sensitivities of the output parameters: $\sigma_{\max }^{1}$ for $a$ ) solid stem; $b$ ) IAM stem; $\sigma_{\max }^{2} ; c$ ) solid stem; $d$ ) IAM stem; and $\sigma_{\max }^{M}$ for $e$ ) solid stem; $f$ ) IAM stem

Table 4 shows the correlation coefficients between the input and output parameters for the solid and IAM stems. Here, it is shown the statistical interdependence between the input and output parameters. The values being closer to zero show that the two parameters are weakly correlated. However, the values being closer to 1 or -1 , show that the two variables are highly correlated either in positive or negative sense, respectively. 
Table 4

Correlation coefficients between the input and output parameters for solid and IAM stems

\begin{tabular}{|c|c|c|c|c|c|c|}
\hline \multirow{2}{*}{ Parameters } & \multicolumn{3}{|c|}{ Solid stem } & \multicolumn{3}{c|}{ IAM stem } \\
\cline { 2 - 7 } & $\sigma_{\max }^{1}(\mathrm{MPa})$ & $\sigma_{\max }^{2}(\mathrm{MPa})$ & $\sigma_{\max }^{M}(\mathrm{MPa})$ & $\sigma_{\max }^{1}(\mathrm{MPa})$ & $\sigma_{\max }^{2}(\mathrm{MPa})$ & $\sigma_{\max }^{M}(\mathrm{MPa})$ \\
\hline$E_{C a n}(\mathrm{MPa})$ & -0.799 & -0.320 & --- & -0.801 & -0.304 & 0.010 \\
\hline$E_{C o r}(\mathrm{MPa})$ & 0.191 & -0.038 & -0.002 & 0.187 & -0.036 & 0.003 \\
\hline$E_{M}(\mathrm{MPa})$ & 0.002 & 0.004 & 0.007 & 0.001 & -0.001 & 0.010 \\
\hline$v_{C a n}$ & -0.006 & --- & 0.004 & -0.006 & -0.002 & -0.008 \\
\hline$v_{C o r}$ & 0.025 & --- & -0.011 & 0.025 & 0.004 & -0.004 \\
\hline$v_{M}$ & -0.004 & -0.006 & 1.000 & -0.007 & -0.003 & 1.000 \\
\hline
\end{tabular}

4. Discussion. In this work, a probabilistic design strategy is established to compare in details the role of different input and output parameters considered when designing the solid and hollow (IAM) stems. Monte Carlo technique is used as a robust tool with a big number of simulations to provide with accurate results. The histograms of the probability density function of three output parameters are presented. The three output parameters have three different distribution forms: The maximum von Mises stress values for the cortical tissue $\left(\sigma_{\max }^{1}\right)$ has the lognormal distribution form. The maximum von Mises stress values for the cancellous tissue $\left(\sigma_{\max }^{2}\right)$ has the exponential distribution form. The maximum von Mises stress values for the metal $\left(\sigma_{\max }^{M}\right)$ has the uniform distribution form. The skewness values of the input values (asymmetry) for the IAM stem differ from those for the solid stem, while there is no big difference when considering the output parameters. The sensitivity analysis for the output parameters with respect to the input random variables is next carried out in order to determine the input parameter influence. Three input parameters $\left(E_{C a n}, E_{C o r}\right.$ and $v_{C o r}$ ) have different roles on the maximum von Mises stress values for the cortical tissue $\left(\sigma_{\max }^{1}\right)$. Here, there is a small difference when comparing the diagram for the solid and IAM stems. For the maximum von Mises stress values for the cancellous tissue $\left(\sigma_{\max }^{2}\right)$, two input parameters $\left(E_{C o r}\right.$ and $\left.E_{C a n}\right)$ play significant roles when considering the IAM stem, while only one input parameter $\left(E_{C o r}\right)$ when considering the solid stem. For the maximum von Mises stress values for the metal $\left(\sigma_{\max }^{M}\right)$, only one input parameter $\left(v_{M}\right)$ has a significant influence for the solid and IAM stems. According to the correlation study, the correlation coefficients between the input parameters and the output ones for the IAM stem are much higher than those for the solid stem where several values are closer to zero. According to the presented probabilistic design strategy, the IAM stem has several advantages relative to the solid one.

5 Conclusion. A probabilistic design strategy is applied to find different probabilistic bounds with high reliability (confidence) levels. The results show that the IAM stem is much more advantageous than the solid stem especially. This study was limited to a $2 \mathrm{D}$ modeling in order to reduce the computing time since 30000 simulations were performed. However, in future work, it is recommended to perform a 3D modeling and to deal with anisotropy behavior for bone tissues.

\section{References}

1. Gonzalez CD. Probabilistic Finite Element Analysis of Un-cemented Total Hip Replacement, PhD thesis. School of Engineering Sciences, Bioengineering Sciences Research Group: University of Southampton; March 2009.

2. Kharmanda G, Antypas I. Reliability-based design algorithm for artificially replaced hip prosthesis considering material property uncertainty. Journal of Advances in Engineering Research, AER. 2018. Advances in Engineering Research (AER). 2018;157:44-50. https://www.atlantis-press.com/proceedings/aime-18/25901891

3. Kharmanda G, El-Hami A, Ibrahim MH. Integration of reliability and optimization concepts into orthopedic prosthesis design: Application on hip prosthesis design. Journal of Uncertainties and Reliability of Multiphysical Systems. 2017. DOI: 10.21494.ISTE.OP.2017.0120

4. Kharmanda G, Albashi L. Numerical Study for Increasing Efficiency of Artificially Un-cemented Hip Joint. Research Journal of Aleppo University, Engineering Science Series. 2011;101:47-64.

5. Kharmanda G, Mulki S, Sabsabi Y. Compter-Aided Design of Internal Replacement Models in Orthopedics Surgery. Research Journal of Aleppo University, Engineering Science Series. 2012;105:312-328. 
6. Kharmanda G. Integration of multi-objective structural optimization into cementless hip prosthesis design: Improved Austin-Moore model, Computer Methods. Biomechanics and Biomedical Engineering. 2016;19(14):15571566. DOI: 10.1080/10255842.2016.1170121

7. Mackerle J. Finite element modeling and simulations in orthopedics. Bibliography 1998-2005, J. Computer Methods in Biomechanics and Biomedical Engineering. 2006; 9(3):149-199. DOI: 10.1080/10255840600751523

8. Senapati S-K, Pal S. UHMWPE-alumina Ceramic Composite. A Proposed Metal Substitute for Artificially Replaced Hip Joint. IE (I) Journal MC. 2005;85:157-162. https:/www.researchgate.net/scientificcontributions/2092553592_SK_Senapati.

9. Shaik SA, Bose K, Cherukuri HP. A study of durability of hip implants. Materials and Design. 2012;42:230-237. DOI: 10.1016/j.matdes.2012.05.049

10. Beaupré GS, Orr TE, Carter DR. An approach for time-dependent bone modeling and remodelingapplication: a preliminary remodeling simulation. Journal of Orthopaedic Research. 1990;8(5):662-670. DOI: http://dx.doi.org/10.1002/jor.1100080507

11. Kharmanda G, El-Hami A. Reliability Concept. Reliability in Biomechanics. 2016:63-112. DOI: 10.1002/9781119370840.ch2 P.

12. Haldar A, Mahadevan S. Probability, reliability and statistical methods. Engineering design. New York, USA: John Willey \& Sons; 2000. P. 304. https://books.google.ru/books?id=wZNRAAAAMAAJ\&redir_esc=y

13. McKay MD, Beckman RJ, Conover WJ. A comparison of three methods for selecting values of input variables. The analysis of output from a computer code. Technometrics. 1979;42:55-61. DOI: 10.1080/00401706.1979.10489755

14. Kharmanda G, Antypas I. Integration of Reliability Concept into Soil Tillage Machine Design. Vestnik of Vestnik of Don State Technical University. 2015;15(2):22-31. DOI: https://doi.org/10.12737/11610

15. Jeppsson J. Reliability-based assessment procedures for existing concrete structures: PhD dissertation. Division of Structural Engineering, Lund University. 2003. P. 199.

16. Cheal E, Spector M, Hayes W. Role of loads and prosthesis material properties on the mechanics of the proximal femur after total hip arthroplasty. Journal of Orthopaedic Research. 1992;10(3):405-422. DOI: http://dx.doi.org/10.1002/jor.1100100314

17. Kayabasi O, Ekici B. Probabilistic design of a newly designed cemented hip prosthesis using finite element method. Materials and Design. 2008;9(5):963-971. DOI: 10.1016/j.matdes.2007.03.024

Submitted 18.05.2020

Scheduled in the issue 20.07.2020

Authors:

Ghais Kharmanda, Guest Researcher, LMN, INSA Rouen Normandie (St. 685 avenue de 1 universite BP08, 76801 Saint-Etienne-du-Rouvary, LMN, INSA Rouen Nomandie, France), Cand.Sci. (Eng.)., ResearcherID: O-66902018, ORCID: https://orcid.org/0000-0002-8344-9270, g.kharmanda@gmail.com

Imad R. Antypas, associate professor of the Machine Design Principles Department, Don State Technical University (1, Gagarin Square, Rostov-on-Don, 344000, RF), Cand.Sci. (Eng.), ResearcherID: O-4789-2018, ORCID: https://orcid.org/0000-0002-8141-9529, Imad.antypas@mail.ru

\section{Claimed contributorship}

G. Kharmanda: scientific guidance, statement of the problem, definition of research methodology; collection and analysis of analytical and practical materials on the research topic, critical analysis and finalization of the solution; computer realization of the solution of the problem. I.R. Antypas: analysis of analytical and practical materials on the research topic and analysis of scientific sources on the topic of research, critical analysis and revision of the text.

All authors have read and approved the final version of the manuscript. 